\title{
The Utilization level of Corn Cob Fermented by MOIYL on Dry Matter and Organic Matter Digestibility on Local Rabbit
}

\author{
Noviani, Yunilas, Ma'ruf Tafsin \\ Animal Production Program Study, Faculty of Agriculture, University of Sumatera Utara, Medan 20155, \\ Indonesia. \\ E-mail: Novianirevan@gmail.com
}

\begin{abstract}
The study aims to evaluated the value of dry matter and organic matter digestibility of feed containing corn cob fermented by MOIYL on local rabbit. Research conducted at Desa Bandar Klippa Deli Serdang, North Sumatera Province, in January - March 2018. The study used 20 local rabbit with initial weight 404,4 gram $\pm 9,14$ and design experiment used completely randomized design (CDR), which consists of 4 treatments and five replications. The treatment consisted of ration $\mathrm{P} 0=$ unfermented $, \mathrm{P} 1=10 \%, \mathrm{P} 2=20$, and $\mathrm{P} 3=$ $30 \%$. Variable measured were consumption of dry matter and organic matter, digestibility of dry matter and organic matter. The Results showed that fermented of corn cob with probiotics MOIYL provide a significant effect $(\mathrm{P}<0,01)$ increasing corn cob fermented by MOIYL to the level $30 \%$ increase dry matter and organic matter digestibility. The conclusion of this study is corn cob fermantation by probiotics MOIYL till the level 30\% can increase the digestibility of dry matter and organic matter on local rabbit.
\end{abstract}

\section{Introduction}

Rabbits are non-ruminant herbivores, most of which are forage requirements. The availability of forage is not sustainable throughout the year due to the influence of the season and the lack of agricultural land. The availability of forage in the rainy season is abundant, while in the dry season the availability is reduced, both in quality and quantity. In these conditions, making alternative feed is needed as a substitute forage. Feed is the main factor that can determine the success of a farm. Availability of inadequate animal feed is a matter of continuity, so it needs to be addressed with various innovations optimally. Rabbits are pseudo-ruminant animals so that rabbits are also able to consume forage, vegetable waste, and feed products that are easily available or cheap. The nutritional quality of feed in rabbits also needs to be considered. Good feed quality is usually available in commercial rations. Commercial rations for rabbits on the market tend to have high prices so alternatives are needed to find feed that is available continuously, cheap, easily available, has sufficient nutritional value, and does not interfere with livestock health.

One alternative animal feed that has the potential and can be utilized is corn cob waste. Corn cobs are part of corn fruit that has been taken by the seeds. The components of old corn and ready to harvest consist of $38 \%$ seeds, $7 \%$ cob, $12 \%$ skin, $13 \%$ leaves and $30 \%$ stems, corn cobs can be given to livestock as a substitute for forage (Statistics Indonesia North Sumatra Province, 2015).

Corn cobs are low quality agricultural products. High fiber content, protein and low digestibility, where the dry matter content is $90 \%$, ash content $1.9 \%$, coarse protein $3.6 \%$, crude fat $0.8 \%$, crude fiber $40.2 \%$, BETN $53.5 \%$, Cellulose 28\%, lignin 7\%, TDN 50\% (Perry et al., 2003) therefore the role of biotechnology is needed to improve the quality of corn cobs, one of which is by fermentation using local Indigenius microorganisms. Local Microorganisms Indigenius is an exploited microorganism from its own substrate which has optimal ability in fiber degradation (Yunilas, 2013). According to Dwi (2015), corn cobs inoculated with 5\% fungi Trichoderma sp. can reduce organic matter and increase crude protein content. Yulistiani et al (2012) reported that corn cobs fermented using Aspergillus niger microbes produced $4 \%$ crude protein content while corn cobs fermented with Trichoderma virede produced $3.4 \%$ protein. The composition of corn cobs protein that has been 
fermented using microbes in general has increased, from 3\% to 6.1\% (Warisman, 2014). Research Objectives To test and determine the effect of using fermented corn cobs feed using MOIYL tehadap digestibility of dry matter and organic matter for male local rabbits feed.

\section{Research Materials and Methods}

\subsection{Time and Place of Research}

This research was carried out in Bandar Klifah Village, Deli Serdang District, North Sumatra Province. Laboratory of Nutrition Sciences and Animal Feed Materials Animal Husbandry Study Program Faculty of Agriculture, University of North Sumatra and Laboratory of Research on Goat Meat Research, Sei Putih Galang. This study lasted for 8 weeks from January 2018 - March 2018.

\subsection{Materials and Research Tools}

The material used was male local rabbits as many as 20 animals with an average initial body weight of 404.4 grams \pm 9.14 . Treatment pellets consist of fine bran, corn, soybean meal, coconut cake, fermented corn cobs, molasses, mineral mix, MOIYL Probiotics consisting of Bacillus sp YLB1, Trichoderma sp YLF8 and Saccharomyces sp YLY3, drinking water, medicines and vitamins such as wormectin , B-complex, antibloat, rodalon as a cage disinfectant. The tool used is a cage of 20 units with a size of $50 \times 50 \times 50 \mathrm{~cm}$, printer pellets, weight scales with a capacity of $15 \mathrm{~kg}$ with sensitivity of $10 \mathrm{~g}$, electric scales with a capacity of $3 \mathrm{~kg}$ with a sensitivity of $1 \mathrm{~g}$, feed and drinking places in each cage with a total of 20 units, cage cleaning tools, cage lighting tools, ovens to dry feed ingredients and analyze feces, chopper machines to chop corn cobs, grinders to smooth feed ingredients and stationery to write data.

\subsection{Research methods}

The research method used was experimentally using a completely randomized design (CRD) consisting of 4 treatments and 5 replications.

The treatment given is as follows:

P0: Feed without fermented corn cobs

P1: Feed with $10 \%$ fermented corn cobs

P2: Feed with $20 \%$ fermented corn cobs

P3: Feed with $30 \%$ fermented corn cobs

Model matematik percobaan yang digunakan adalah rancangan acak lengkap (RAL) adalah :

$$
\mathbf{Y}_{\mathrm{ij}}=\boldsymbol{\mu}+\boldsymbol{\sigma}+\varepsilon_{\mathrm{ij}}
$$

\section{Dimana :}

$$
\begin{array}{ll}
\mathrm{i} & =1,2,3 \ldots \ldots \ldots \text { perlakuan } \\
\mathrm{j} & =1,2,3 \ldots 0 \ldots \ldots \ldots \text { ulangan } \\
\mathrm{Y}_{\mathrm{ij}} & =\text { nilai pengamatan dari perlakuan ke-I dan ulangan ke- } \mathrm{j} \\
\mu & =\text { nilai tengah umum } \\
\sigma & =\text { pengaruh perlakuan ke-i } \\
\varepsilon_{\mathrm{ij}} & =\text { Pengaruh galat percobaan dari perlakuan ke-I pada ulangan ke-j }
\end{array}
$$

Tabel 1. The composition of the research treatment (randomization treatment and replication)

\begin{tabular}{lllll}
\hline $\mathrm{P}_{2} \mathrm{U}_{3}$ & $\mathrm{P}_{0} \mathrm{U}_{2}$ & $\mathrm{P}_{1} \mathrm{U}_{4}$ & $\mathrm{P}_{3} \mathrm{U}_{2}$ & $\mathrm{P}_{2} \mathrm{U}_{2}$ \\
$\mathrm{P}_{3} \mathrm{U}_{4}$ & $\mathrm{P}_{1} \mathrm{U}_{3}$ & $\mathrm{P}_{0} \mathrm{U}_{3}$ & $\mathrm{P}_{2} \mathrm{U}_{1}$ & $\mathrm{P}_{1} \mathrm{U}_{1}$ \\
$\mathrm{P}_{0} \mathrm{U}_{1}$ & $\mathrm{P}_{2} \mathrm{U}_{4}$ & $\mathrm{P}_{2} \mathrm{U}_{5}$ & $\mathrm{P}_{1} \mathrm{U}_{5}$ & $\mathrm{P}_{3} \mathrm{U}_{3}$ \\
$\mathrm{P}_{1} \mathrm{U}_{2}$ & $\mathrm{P}_{3} \mathrm{U}_{5}$ & $\mathrm{P}_{3} \mathrm{U}_{1}$ & $\mathrm{P}_{0} \mathrm{U}_{4}$ & $\mathrm{P}_{0} \mathrm{U}_{5}$ \\
\hline
\end{tabular}


2.3. The variables observed

Dry matter digestibility and organic matter digestibility

2.4. With formula

Kecernaan BO $=$ konsumsi BO (gram) - BOfeses (gram) x 100\% konsumsi BO (gram)

Kecernaan BK = konsumsi BK (gram) - BK feses (gram) $\times 100 \%$ konsumsi BK (gram)

The data obtained were analyzed using analysis of variance (ANOVA) if among the treatments there was a real effect, it would be continued by using the Duncan Distance Difference Test (BNJD).

\subsection{Research Implementation}

Preparation of cages and equipment, preparation of rabbits, randomization of rabbits, processing of corn cobs waste, feeding and drinks, administration of drugs and data collection.

\section{Results and discussion}

\subsection{Consumption of Dry Material}

Consumption of local rabbits dry matter is calculated based on the dry matter contained in the feed. Data collection on dry matter consumption was taken during the last seven days of local rabbit maintenance. Data on average of local rabbit dry matter consumption can be seen in Table

Table 2. Average consumption of local rabbit dry matter (gram / head / day).

\begin{tabular}{lcccccc}
\hline Perlakuan & \multicolumn{3}{c}{ Ulangan } & & Rataan \pm Sd \\
\hline & U1 & U2 & U3 & U4 & U5 & \\
\hline P0 & 63,95 & 65,38 & 66,10 & 64,55 & 64,43 & $64,88 \pm 0,85^{\mathrm{A}}$ \\
P1 & 68,27 & 69,22 & 69,93 & 70,76 & 71,23 & $69,88 \pm 1,18^{\mathrm{B}}$ \\
P2 & 71,95 & 72,3 & 71,95 & 71,60 & 72,89 & $72,14 \pm 0,49^{\mathrm{C}}$ \\
P3 & 75,09 & 75,33 & 74,38 & 75,68 & 76,39 & $75,37 \pm 0,74^{\mathrm{D}}$ \\
\hline
\end{tabular}

Description: superscript with different lowercase letters towards the column, shows a very real effect $(\mathrm{P}<0.01)$.

The table shows the average of dry rabbit feed consumption of local rabbits ranged from 64.88 to 75.37 grams / head / day where the lowest average obtained in treatment P0 was 64.88 grams / head / day and the highest average obtained in treatment P3 was equal to 75.37 grams / head / day. The results of the diversity analysis showed that the administration of various levels of fermented corn cobs flour in local rabbit feed gave a very significant effect $(\mathrm{P}<0.01)$ on the consumption of dry matter. The existence of a very significant difference in dry matter consumption is thought to be due to the fermentation process in the P3, P2, and P1 treatment feeds which causes higher dry matter consumption compared to the P0 treatment (ration without fermented corncob flour). The fermentation process in feed can affect the quality of feed both from aroma and taste so that it can increase palatability. The treatment of P3 (ration with $30 \%$ fermented corn cobs) has a dark brown color and fragrant aroma while in treatment P0 (ration without fermented corncob) has a brown color and less fragrant aroma. This is consistent with Ningsih's statement (2016) which states that ration consumption is influenced by several factors including ration palatability, physical form of ration, body weight, sex, environmental temperature, hormonal balance and growth phase. The existence of a fermentation process also results in increased consumption of dry ingredients because the fermentation process is able to convert complex compounds into simple so that the feed will be more easily digested. 


\subsection{Consumption of Organic Materials}

Table 3. Average consumption of local rabbit organic matter (gram / head / day).

\begin{tabular}{lcccccc}
\hline Perlakuan & \multicolumn{5}{c}{ Ulangan } & \multicolumn{2}{c}{ Rataan \pm Sd } \\
\hline & U1 & U2 & U3 & U4 & U5 & \\
\hline P0 & 60,61 & 61,97 & 62,65 & 61,18 & 61,07 & $61,49 \pm 0,81^{\mathrm{A}}$ \\
P1 & 64,98 & 65,88 & 66,56 & 67,35 & 67,80 & $66,51 \pm 1,13^{\mathrm{B}}$ \\
P2 & 68,27 & 68,6 & 68,27 & 67,93 & 69,16 & $68,45 \pm 0,46^{\mathrm{C}}$ \\
P3 & 70,46 & 70,68 & 69,79 & 71,01 & 71,68 & $70,72 \pm 0,7^{\mathrm{D}}$ \\
\hline
\end{tabular}

Description: superscript with different lowercase letters towards the column, shows a very real effect $(\mathrm{P}<0.01)$.

The increase of organic matter in each treatment ration was caused by the success of fermentation of corn cobs flour so that the organic matter content increased from $61.49 \%$ to $70.72 \%$. This shows that fermentation with MOIYL can increase the nutritional value of corn cobs flour as animal feed ingredients. In the opinion of Rosningsih (2013) that ingredients undergoing fermentation have a higher nutritional value than their original ingredients. The presence of a fermentation process using MOIYL can also increase feed consumption this is because the fermentation process can add flavor and aroma that is preferred by livestock. This is in accordance with Simanjuntak's (2015) statement, which states that high feed consumption is due to the physical properties of feed, which is reflected in its organoleptic (taste, aroma and texture). The presence of a fermentation process that can add flavor and aroma results in high palatability of feed.

\subsection{Dry Material Digestibility}

Table 4. Average digestibility of dry matter for local male rabbit feed (\%)

\begin{tabular}{|c|c|c|c|c|c|c|}
\hline \multirow[t]{2}{*}{ Perlakuan } & \multicolumn{4}{|c|}{ Ulangan } & \multicolumn{2}{|c|}{ Rataan $\pm S d$} \\
\hline & U1 & $\mathrm{U} 2$ & U3 & $\mathrm{U} 4$ & U5 & \\
\hline P0 & 77,01 & 77,32 & 77,96 & 77,04 & 76,59 & $77,18 \pm 0,51^{\mathrm{A}}$ \\
\hline $\mathrm{P} 1$ & 78,66 & 79,87 & 79,89 & 80,8 & 81,1 & $80,06 \pm 0,95^{\text {В }}$ \\
\hline P2 & 81,11 & 81,92 & 80,93 & 81,21 & 82,92 & $81,61 \pm 0,82^{\mathrm{C}}$ \\
\hline P3 & 83,29 & 82,99 & 82,59 & 83,36 & 83,81 & $83,21 \pm 0,45^{\mathrm{D}}$ \\
\hline
\end{tabular}

Description: superscript with different lowercase letters towards the column, shows a very real effect $(\mathrm{P}<0.01)$.

One of the factors that can affect the dry matter digestibility is the fiber content in the feed, the decrease in fiber from P0, P1, P2 to P3 respectively, which is $14.78 ; 13.95 ; 13.1$ and $12.26 \%$. caused by the fermentation process using MOIYL which can degrade fiber. This is in accordance with Yunilas's statement (2016), which states that MOIYL based on palm oil waste plays a role in degrading fiber (cellulose and hemicellulose) and can be used as a source of high-fiber feed fermentation inoculants. According to Syaifuddin (2010) the more coarse fiber contained in a feed material, the thicker and more resistant the cell wall and consequently the lower digestibility of the feed ingredients. Rohimah (2012) stated that the dry matter digestibility of rabbits given a complete pellet-shaped ration was $47 \%$. From the results of the study showed higher dry matter digestibility than the study reported by Rohimah (2012) that is equal to $77.18-83.21 \%$. This is due to the nature of coprophagy in rabbit herds and not the prevention of coprophagy in this study which results in high digestibility. Prevention of caecotrophy in 6-8 week old rabbits causes a decrease in growth and a decrease in protein digestibility from $77 \%$ to $60 \%$. According to Prasetiya (2010) the coprophagy properties allow rabbits to fully utilize the lower digestion of bacteria, which converts forage protein into high-quality bacterial protein, synthesizes vitamin B and breaks cellulose or fiber into useful energy. 
Table 5. Average digestibility of organic matter for male local rabbit feed (\%)

\begin{tabular}{lcccccc}
\hline Perlakuan & \multicolumn{3}{c}{ Ulangan } & \multicolumn{2}{c}{ Rataan \pm Sd } \\
\hline P0 & U1 & U2 & U3 & U4 & U5 & \\
P1 & 80,22 & 80,47 & 81,04 & 80,22 & 79,84 & $80,36 \pm 0,44^{\mathrm{A}}$ \\
P2 & 81,72 & 82,6 & 82,63 & 83,31 & 83,57 & $82,77 \pm 0,72^{\mathrm{B}}$ \\
P3 & 83,52 & 84,22 & 83,37 & 83,61 & 85,13 & $83,97 \pm 0,72^{\mathrm{C}}$ \\
\hline
\end{tabular}

Description: superscript with different lowercase letters towards the column, shows a very real effect $(\mathrm{P}<0.01)$.

The digestibility of organic matter in the experiment has the same pattern as the dry matter digestibility. The relative digestibility of organic matter was higher than the dry matter digestibility in each treatment. This is because the dry matter still contains ash, while the organic material does not contain ash, so the material without ash content is relatively easier to digest. Fathul and Wajizah (2010) stated that the ash content can slow or inhibit the dryness of dry matter.

Organic digestibility in P3 treatment is higher than treatment P2, P1 and P0, due to the fermentation process using MOIYL whose components consist of bacteria, fungi and yeast in the form of Bacillus sp YLB1, Tricoderma sp YLF8 and Saccharomyces sp YLY3 which have the ability to degrade fiber so its digestibility increases. According to Supriyati et al., (1998) fermentation using mold allows the overhaul of material components that are difficult to digest become more available, so that it is also expected that nutritional value will increase. Organic matter digestibility which is high including range of $80.36-85.36 \%$ due to the grinding process on corn cobs. This process can break down the lignin content in corn cobs, causing high digestibility. This is consistent with the statement of Sabrina (2014) which states that the lignin content of corn cobs which can inhibit hydrolysis can be overcome by delignification. The delignification process is by grinding corn cobs. In addition, lignase enzymes which are also produced by Aspergillus niger can break the lignin bonds of polysaccharides into simpler parts. Saccharomyces cerevisiae is also one of the most commonly used lines for fermentation, because it is strong fermentative and facultative anaerobes (able to live with or without oxygen), have stable and uniform properties, are able to grow quickly during fermentation so the fermentation process takes place quickly also.

\section{Conclusion}

The utilization of fermented corn cobs using MOIYL to the level of $30 \%$ can increase the digestibility of dry matter and organic matter for local rabbit feed.

\section{References:}

[1] Central Bureau of Statistics, North Sumatra Province. 2015. Corncob Waste in Figures 2015.

[2] Dwi, Y, A. 2015. Content of Organic Ingredients and Coarse Proteins Corn Cobs (Zea Mays) Inoculated with Trichoderma Fungi Sp. At Old Different Incubation. Essay. Faculty of Agriculture, University of Hassanudin. Macassar.

[3] Fathul, F and S. Wajizah. 2010. Addition of Mn and Cu Micromineral in the Ration to Lamb Rumen Biofermentation Activity in In Vitro. JITV 15 (1) 9-15

[4] Ningsih, R. 2016. Digestibility of Dry and Organic Ingredients Gamal and Lamtoro Mixed Basal Rations with Multi Nutrition Supplements in Ethawa Goat Goats. Essay. Faculty of Animal Husbandry. Hasanuddin University. Macassar.

[5] Perry TW, Cullison AE, Lowrey RS. 2003. Feeds and Feeding. 6th Ed. New Jersey: Prentice all inc.

[6] Simanjuntak, S., Yunilas, and M, Tafsin. 2015. Fermentation of By-Products of Oil Palm industries and Plantations with Local Probiotics Against Performance of Sheep. Journal of Animal Husbandry Integrative Vol.4. No.1 December 2015: 83-95.

[7] Sabrina, Y. 2014. Local Microbial Use Against Digestibility of Dry Ingredients and Organic orncob Materials Invitro. Essay. Faculty of Agriculture, North Sumatra University. Field. 
[8] Supriyati, T. Pasaribu, H. Hamid and A. Sinurat, 1998. Fermentation of Palm kernel meal in solid substrate using Aspergillus niger. Journal of Animal and Veterinary Sciences.

[9] Syaifuddin, I, A. 2010. Use of Fermented Cocoa Fruit Skin Flour in the Ration Against Digestibility of Dry and Digestive Ingredients of New Zealand White Male Rabbit. Thesis. Faculty of animal husbandry, Sebelas Maret University. Surakarta.

[10] Warisman. 2014. Biological Processing in Improving the Quality of Nutrition Corn Cobs Fermented as Lamb Feed. Thesis. Animal Husbandry Study Program Faculty of Agriculture, University of North Sumatra. Field.

[11] Yunilas. 2016. The Role of Indigenous YL Microorganisms (MOIYL) as Inoculums for Degradation of Fiber Based on Oil Palm Plantation Waste. Proceedings of the National Seminar on Sustainable Livestock 8, 16 November 2016. Sumedang. Indonesia.

[12] Yunilas, Lili Warly, Yetti Marlida., And Irsan Ryanto. 2013. Protency of Indeginous Bacteria From Palm Oil Waste in Degrades Lignocellulose as a Sources of Inoculum Fermented to High Fiber feed. Pakistan Journal of Nutrition 12 (9): 851-853.

[13] Yulistiani, D. 2012. Corn Cob Silage for Ruminant Animal Feed. Sinartani Tabloid gricultural Research Agency. July 18-24 Edition No. 3466 